\section{BIBLIOGRAPHY:}

Kокоszко M., Ryby i ich znaczenie w życiu codziennym ludzi późnego antyku i wczesnego Bizancjum (III-VII w.), Łódź 2005.

Кокозzко M., Smaki Konstantynopola, [in:] Konstantynopol - Nowy Rzym. Miasto i ludzie w okresie wczesnobizantyńskim, ed. M.J. LeszKA, T. WoLIŃsKA, Warszawa 2011, p. 471-575.
Koкoszko M., Jagusiak K., Rzeźnicka Z., Zboża $i$ produkty zbożowe $w$ źródłach medycznych antyku $i$ wczesnego Bizancjum (II-VII w.) [= Dietetyka $i$ sztuka kulinarna antyku $i$ wczesnego Bizancjum (II-VII w.), vol. I], Łódź 2014.

Krzysztof Jagusiak (Łódź)*

*Uniwersytet Łódzki, Centrum Ceraneum

DOI: 10.18778/2084-140X.07.15

\title{
АНЕТА ДИМИТРовА, Златоструят в преводаческата дейност на старо- българските книжовници [The Zlatostruy in the Translation Work of Old Bulgarian Writers], Авалон, София 2016, pp. 456.
}

$\mathrm{T}$ he book is dedicated to the Zlatostruy, one of the most famous monuments of Old Bulgarian literature from the period of the reign of tsar Simeon (893-927). In particular, the study focuses on the first 45 texts (sermons, or 'slovos') from the long Slavic redaction. The miscellany's remarkable popularity in medieval Bulgaria (and in the sphere of Slavia Orthodoxa in general), attested to by tens of copies, was the effect of several factors. On the one hand, it resulted from the tsar's personal involvement in its compilation, as well as from the reputation of the author of the texts, St. John Chrysostom (350?-407) - one of the most renowned preachers of the Eastern Orthodox Church. The primary reason, however, is probably to be sought in the texts themselves - providing the still newly Christian community with interpretations of the basics of the faith, commenting on fragments of the Holy Bible, glorifying virtues, and condemning sins.

The book by Aneta Dimitrova is an exceedingly meticulous and accurate study of the linguistic and stylistic features of the Zlatostruy. It is divided into four parts.

The first part (Въведение / Introduction, p. 9-78) is an extensive introduction into the topic of the research. Following a presentation of the aims and methods applied in the analysis of the sources (which include 6 Slavic and 23 Greek manuscripts), the author contextualizes the material in both the Slavic and the Greek tradition, lucidly outlining the relations between the various redactions of the Zlatostruy (long, short and 'Hilandar') and the compilation of Simeon I the Great; she also describes the latter's links to the Preslav literary school. The introduction features a separate commentary on the biblical quotations found in the Zlatostruy and their role in the analysis of the text. Although the author points out (p. 61) that the issue requires a separate, detailed study, she feels she cannot skip it entirely in her description. This is due to its importance and its organic relation with the type of texts involved (an ideal environment for biblical quotations in view of both genre and topic). The author points out the obstacles that may be encountered in the course of such research, especially the high degree of variation in biblical quotations in the Greek text, the fact that the original Slavic translation is lost, and the many discrepancies observed among the existing Slavic manuscripts and redactions of the Zlatostruy. The final issue discussed in the introduction is the character of the language of the original Greek text.

The second part (Коментар на словата L1-L45 / Commentary on the sermons / 'slovos' $L 1-L 45$, p. $79-308)$ is the core of the monograph, comprising extensive commentaries on all 45 texts of the Zlatostruy. Each commentary includes the general information on the text's 
location within the collection, the Byzantine original and its variants, the relations between the original text and the translation as well as certain linguistic remarks on the Slavic material. The latter, although understandably not constituting comprehensive studies, refer to several aspects of language - morphology, syntax and vocabulary - thus offering a quite broad view of the topic. In view of the sizable corpus, the author arbitrarily chooses the linguistic problems for her analysis. In the domain of morphology, Dimitrova focuses on the use of archaic forms (e.g. inflectional endings of non-productive declensional types or aorist forms), forms that she considers "innovations" attested in the spoken language from the time, "East Bulgarianisms" or "Balkanisms" (p. 46; the relative pronoun ижєто, the lack of the ending -тү in the $3^{\text {rd }} \mathrm{sg}$. present, etc.), as well as other forms interesting from the point of view of the history of the Bulgarian language (the various ways of expressing the passive voice, the periphrastic future tense with auxiliary verbs serving to render the Greek synthetic future, etc.). In her analysis of the syntax, the author points out the ways in which the translation handles Greek constructions involving the definite article (substantivized, attributive and participial), infinitive with article, accusative and infinitive, as well as genitive and dative absolute; furthermore, she studies the Old Bulgarian verbal constructions with $d a$. As regards the vocabulary of the texts, it may, according to Dimitrova, be divided into the following groups: a) 'Preslav' and 'non-Preslav, Cyrillo-Methodian, archaic', b) words of Greek, Semitic and Proto-Bulgar origin, c) compounds, and d) theological, philosophical and abstract terminology. For each text, the linguistic comments are supplemented by examples, often portraying the most interesting solutions and/or mistakes made by the translators.

The individual commentaries and analyses of each word of the Zlatostruy provided in the second part of the book enable the author to draw some general conclusions in the third part (Обобщение и заключение / Generalizations and conclusions, p. 309-315). These pertain to all of the linguistic aspects discussed above, revealing both similarities and differences among the texts under analysis.

Finally, the annexes - prepared with astonishing fastidiousness - constitute an integral part of the book. They include: a) the distinctive features of the translations (p. 335-356), b) the equivalents of constructions with the article in individual texts (p. 357-365), and c) an Old Bulgarian-Greek and Greek-Old Bulgarian dictionary of selected lexemes attested in the material (p. 367-444).

The impact of this publication on the general scholarship on the Zlatostruy is indisputable. Furthermore, one cannot underestimate its value for comparative research on language history and textology. It is only to be hoped that in her future research, the author - after such arduous philological work, part of which could not be included in the publication - will resolve to develop the points she had to forego at this stage, and that she will apply the same impressive level of commitment.

Agata Kawecka (Łódź)

\footnotetext{
* Uniwersytet Łódzki, Wydział Filologiczny, Katedra Filologii Słowiańskiej
}

DOI: $10.18778 / 2084-140 X .07 .16$

\begin{abstract}
MARCIN BöHM, Rola flot obcych $w$ procesie ostatecznego rozkladu sil morskich cesarstwa bizantyńskiego (1118-1204) [The Role of Foreign Fleets in the Decomposition of the Naval Forces of Byzantium], Napoleon V, Oświęcim 2016, pp. 239.
\end{abstract}

$\mathrm{O}$ ne of the main areas of interest of Marcin Böhm - a historian of the University of Opole and the author of the reviewed book
- is the fleet in the Middle Byzantine period. He dedicated one of his books so far to this subject, which was based upon his $\mathrm{PhD}$ thesis titled: 